DOI 10.11603/ijmmr.2413-6077.2016.1.6376

\title{
EPIDEMIOLOGICAL AND EPIZOOTIC ASPECT OF LEPTOSPIROSIS EVOLUTION IN TERNOPIL REGION
}

\author{
N. A. Vasylieva, Yu. A. Kravchuk \\ I. HORBACHEVSKY TERNOPIL STATE MEDICAL UNIVERSITY, TERNOPIL, UKRAINE \\ TERNOPIL REGIONAL LABORATORY CENTRE OF THE STATE SANITATION AND EPIDEMIOLOGICAL \\ SERVICE OF UKRAINE, TERNOPIL, UKRAINE
}

Background. Ternopil region is endemic on leptospirosis. Its natural conditions (slightly alkaline or alkaline soils, air temperature, sufficient rainfall) contribute to the existence of major natural reservoir of the pathogen mouse-like rodents. In the region, different serovariants of leptospira are exuded by rodents and farm animals.

Objective. The materials of the Department of Highly Infectious Diseases of Ternopil Regional Laboratory Centre of the State Sanitation and Epidemiological Service of Ukraine, Ternopil Regional Laboratory of Veterinary Medicine, Clinic of Infectious Diseases of TSMU were studied.

Leptospiras were detected by dark ground microscopy (DFM) of blood of patients, trapped rodents and examined farm animals.

Results. The circulating of pathogens between different sources (rodents, animals) and annual disease incidence evidences that new leptospira serovar are carried onto endemic area mostly by farm animals; humans are infected from them through the environment sometimes in 3-5 years intervals; the further diffusion to the new areas of this pathogen serovars in all kinds of the examined mouse-like rodents is noticed.

It is established that farm animals and rodents are competing reservoirs. To predict the future epidemiological situation of leptospirosis among the humans and to improve its diagnosis the constant monitoring of the population, infection and leptospira carriage among mouse-like rodent and farm animals and expanding of the panel of diagnostic leptospira strains including new pathogen variants in animals is necessary.

Conclusions. The development of additional reservoirs in animals, with circulating of other pathogen serovars among them, such as mouse-like rodents, which were previously absent in the main natural reservoir, cause the change of etiological structure in human leptospirosis at the endemic areas. The range of human leptospirosis pathogens and its further spreading among all kinds of rodents increased during our research. The results of detection of leptospirosis pathogens among the various contingents which were studied evidence that the farm animals and rodents are competing reservoirs that cause human infection through environment.

KEY WORDS: leptospirosis, disease incidence, source of infection, rodents, farm animals.

\section{Introduction}

Leptospirosis is a common infectious disease among humans and animals. The features of this disease are: mostly severe course, high mortality, and great social and economic losses. Every year more than 1.03 million cases and 58.900 deaths happen due to leptospirosis in the world. The highest incidence and mortality rate is in South and Southeast Asia, Oceania, Latin America, East Africa [1]. This disease was recorded in almost all regions of Ukraine, in Ternopil region as well.

Corresponding author: Nataliya Vasylieva, Department of Infectious Diseases and Epidemiology, Dermatology and Venereology, I. Horbachevsky Ternopil State Medical University, 1 Maidan Voli, Ternopil, Ukraine, 46001

Tel.: +380352524725

E-mail: vasylyeva@tdmu.edu.ua
The mouse-like rodents and natural conditions (slightly alkaline and alkaline soils, sufficient rainfall, appropriate air temperature [2, 3]) as main natural pathogen reservoir define the endemicity of leptosirosis area and contribute to preservation and dissemination of this disease.

The aim of the research was to investigate regularities of epidemic and epizootic processes of leptospirosis and study it's pathogen circulation between different nidi (rodents, animals) and person.

\section{Materials and Methods}

The materials of the Department of Highly Infectious Diseases of Ternopil Regional Laboratory Centre of the State Sanitation and Epidemiological Service of Ukraine, Ternopil Re- 
gional Laboratory of Veterinary Medicine, Clinic of Infectious Diseases of TSMU were studied.

Leptospiras were detected by dark ground microscopy (DFM) of blood of patients, trapped rodents and examined farm animals.

Pathogen serovar was determined according to serological investigation in microhemagglutination test of live leptospira cultures (RMAL); standard diagnostic set consisted of 11 leptospira serogroups that consisted of both diagnostic strains proposed by the $\mathrm{WHO}$ and strains registered in Ukraine and identified in accordance with international reference cultures.

The leptospirosis incidence among the humans in Ternopil region in 1980-2014, leptospira contamination of animals at private and collective farms and also rodents in the wild were studied.

\section{Results and Discussion}

In Ternopil region there were two rather large "bath" leptospirosis outbreaks in children (laboratory deciphered L. grippotyphosa) in July 1963 (18 patients) and in August 1972 (22 patients). It happened after swimming in the river, livestock farms were situated upstream of it. The rodents trapped near the river contaminated with leptospira too.

Since 1972 regular monitoring of leptospirosis among the humans took place. The leptospirosis incidence among humans in the region differed: 1,05-12,17 per 100 thousand of population (2-149 cases per year); the highest rate was in 1992-2001, the maximum incidence was in 1994, in $2014-3,26$, which exceeded the average rate in the country all the time and was the highest in Ukraine for many years.

Till 1981 L. grippotyphosa was the main leptospirosis pathogen in humans $(90 \%$ cases etiologically deciphered). The percentage of this leptospira in the structure of leptospirosis decreased by $41,1-51,4 \%$ in $1988-1989$, by $3.4 \%$ in 1994. From 1999-2000 there were no incidence of leptospirosis caused by this pathogen. L. icterohaemorrhagiae was the main etiological factor of this disease in the 90s (in 1991 $93,2 \%$, in $2000-100,0 \%$ ).

The disease was rarely caused by other leptospira serogroups. The disease caused by L. hebdomadis $(5,9-45,4 \%)$, L. canicola $(14,2-$ $60,0 \%)$, L. pomona $(3,1-21,4 \%)$ was registered in 2002; the rate of L. icterohaemorrhagiae decreased by $37.5 \%$, there were only some rare cases of L. grippotyphosa (Fig. 1). The rate of combined leptospirosis significantly increased in recent years (34.3\% of all registered in 2014).

The etiologic spectrum of leptospirosis in humans and in mouse-like rodents in the first stage of observation did not coincide (19811993). In the natural habitats the antibodies to leptospira of Grippotyphosa serogroup were found in mostly different kinds of voles, field and house mice; only to Icterohaemorrhagiae - in domestic grey rats. Hebdomadis segroup was also found in voles and mice and at home foci as well. During the same period the disease caused by the above mentioned pathogens as well as Canicola and Pomona (1982) (Fig. 1), further Kabura (2005) Polonica (2007), was registered in humans, but in rodents these pathogens had not been found before that

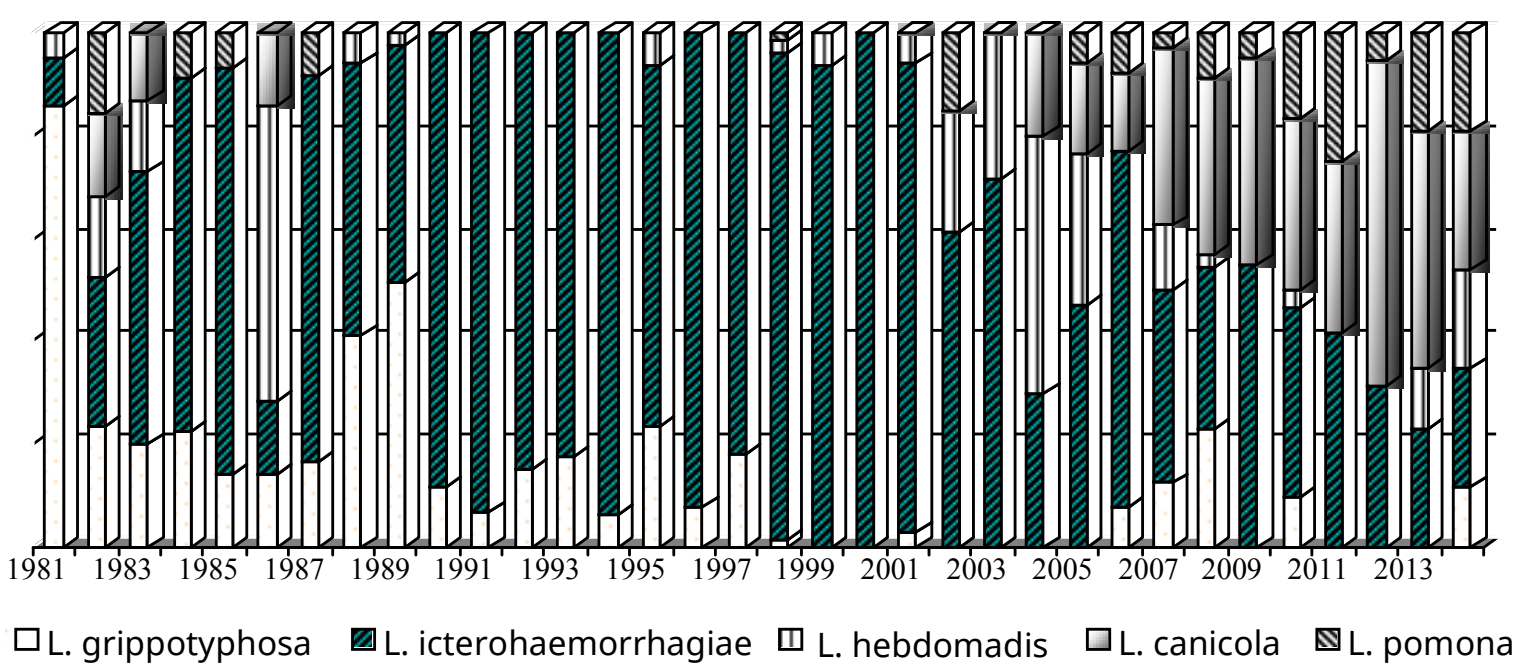

Figure 1. Etiological structure of human leptospirosis incidence in Ternopil region (annual percentage fraction of pathogens, 1980-2015, \%). 
time. In 2010 one case of leptospirosis in humans caused by L. australis was registered. According to the epidemiological anamnesis the source of infection has not been established. The contamination possibly happened at other area.

The animals can be the source of leptospirosis infection too. The vaccination process, natural infection or animal disease might cause their serological positivity. The vaccine do not contain L. kabura, (L. hebdomadis), L. bratislava, which are often detected in animals.

Every year the carriers of leptospirosis and disease incidence in farm animals were registered at private and collective farms of Ternopil region which ended up with animal death and abortion; from 1983 epizootic diseases were rare, clinically apparent forms of leptospirosis were not registered, however, sufficiently high titers (1:400) of antibodies were defined, which evidenced about carrying or subclinical form of the disease in animals and we should consider them as potential sources of leptospirosis for humans. It is possible that the animals' infection happened after restocking from other farms and areas.

According to the recent researches, the duration of leptospirosis carrying in cattle is up to 6 months: in pigs - up to1 year; $10 \%$ of cattle and $30 \%$ of pigs are carriers for life, as well as rats and mice [4]. However, some authors believe that at most areas the domestic and farm animals are not very important for the epidemiology of leptospirosis because rats usually are revealed at these loci [5].

Etiological structure of animal leptospirosis is diverse and includes L. icterohaemorrhagiae, pomona, grippotyphosa, hebdomadis, polonica, canicola, kabura, tarassovi; L. bratislava was registered in 2007 (87.5\% in pigs in 2008), often diagnostically significant titers of antibodies to two different serovars are defined at the same time (71,4-78,0\% in cattle in 2003-2006).

Till 1983 only leptospira of Grippotyphosa and Icterohaemorrhagiae serogroups, sometimes of Hebdomadis, was detected; later antibodies to other serovars were identified: Canicola in rats (2004), Kabura (2006) in different kinds of voles, except Grippotyphosa, also Icterohaemorrhagiae, Pomona, Canicola, Hebdomadis; the expanding of pathogens and their further distribution in all kinds of examined mouse-like rodents took place. In 2015 leptospira Polonica was identified in rodents for the first time.

The range of serologically identified pathogens was listed during the monitoring of humans, farm animals and mouse-like rodents (Table 1).

Due to this study and our previous researches [6-8] we verify that leptospira serovars in farm animals cause the human diseases because these pathogens were not exuded by rodents in this region before. New leptospira serovars, which are carried mostly by farm animals and humans are infected through environment from them, in humans are usually registered in 3-5 years after they are exuded from animals. We also evidence the further spread of the new pathogen serovars at this area in all kinds of examined mouse-like rodents.

So, it was proved that farm animals and rodents are competing reservoirs of leptospirosis pathogens. To predict future epidemiological situation of leptospirosis in humans and to improve its diagnosis the monitoring of the population, infection and leptospira carriage among mouse-like rodents and farm animals and expanding of the panel of diagnostic leptospira strains including new pathogen variants in animals is necessary.

Table 1. Leptospirosis pathogens serologically identified in humans, farm animals and rodents (1972-2015).

\begin{tabular}{|c|c|c|}
\hline Rodents & Farm animals & Humans \\
\hline L. icterohaemorrhagiae (1972) & L. icterohaemorrhagiae (1972) & L. icterohaemorrhagiae (1972) \\
\hline L. grippotyphosa (1972) & L. grippotyphosa (1972) & L. grippotyphosa (1972) \\
\hline L. hebdomadis (1983) & L. hebdomadis (1981) & L. hebdomadis (1981) \\
\hline L. canicola (1982, 2004) & L. canicola (1979) & L. canicola (1982) \\
\hline L. pomona (2008) & L. pomona (1979) & L. pomona (1982) \\
\hline L. kabura (2006) & L. kabura (2002) & L. kabura (2005) \\
\hline L. polonica (2015) & L. polonica (2002) & L. polonica (2007) \\
\hline & L. tarassovi (2002) & L. australis (2010) \\
\hline & L. bratislava (2007) & \\
\hline
\end{tabular}


Thus, the factors that contribute to the evolution of the epidemic process in leptospirosis are:

- biological changes of the natural reservoir species composition of rodents, their number and contamination;

- expanding of new leptospira strains into endemic areas of farm animals, which cause human infection through environment and further spread among mouse-like rodents and pathogen establishment there.

Prevention: annual examination for leptospirosis of breeding stock and animals purchased for sale in other farms; sterilization of animal carriers; vaccination; diratisation; draining of wetlands could decrease (possibly avoid) the expanding of new leptospira strains into endemic areas and prevent the disease incidence in humans.

\section{References}

1. Costa F, Hagan JE, Calcagno J et al. Global Morbidity and Mortality of Leptospirosis: A Systematic Review. PLoS Negl Trop Dis 2015; 9 (9): 3898.

2. Виноград НО, Кіріяк ОП, Мурзова ЛІ та ін. Еколого-епідеміологічні особливості лептоспірозу на Івано-Франківщині. Сучасні інфекції 2004; 1: 60-65.

3. Кравчук ЮА, Васильєва НА. Епізоотологоепідеміологічні особливості лептоспірозу в Тернопільській області. Анали Мечниківського інституту 2015; 2: 165-171.

4. Задорожна ВI, Протас СВ, Гопко НВ та ін. Епізоотологічні та епідеміологічні аспекти лептоспірозу в Україні. К; 2014: 46.

5. Бернасовська $\in П$, Кондратенко ВМ, Мель-

\section{Conclusions}

1. The development of additional reservoirs in animals, with circulating of other pathogen serovars among them, such as mouse-like rodents, which were previously absent in the main natural reservoir, cause the change of etiological structure in human leptospirosis at the endemic areas.

2 . The range of human leptospirosis pathogens and its further spreading among all kinds of rodents increased during our research.

3 . The results of detection of leptospirosis pathogens among the various contingents which were studied evidence that the farm animals and rodents are competing reservoirs that cause human infection through environment. ницька ОВ. Проблема лептоспірозу в Україні. Інфекційні хвороби 1996; 2: 37-39.

6. Васильєва НА, Буртняк ТВ, Блажкевич БВ, Грузина ЛО. Захворюваність людей на лептоспіроз та інфікованість патогенними лептоспірами гризунів у Тернопільській області. Інфекційні хвороби 1995; 2: 22-25.

7. Васильєва НА, Поліщук ЮА, Івахів ОЛ та ін. Епідеміологічні особливості лептоспірозу в західному регіоні України. Інфекційні хвороби 2008; 2 : 14-18.

8. Васильєва НА, Луцук ОС, Павлів ОВ. Еволюція епідемічного процесу лептоспірозу (за матеріалами Тернопільської області). Профілактична медицина 2011; 2: 69-73.

Received: 2016-02-19 